\begin{tabular}{|c|c|}
\hline \multicolumn{2}{|c|}{ PublisherInfo } \\
\hline PublisherName & Palgrave Macmillan UK \\
\hline PublisherLocation & London \\
\hline PublisherImprintName & Palgrave Macmillan \\
\hline
\end{tabular}

\title{
Globalisation: what are the main statistical challenges?
}

\begin{tabular}{|c|c|c|}
\hline \multicolumn{3}{|c|}{ ArticleInfo } \\
\hline ArticleDOI & : & 10.1057/palgrave.elmr.1410136 \\
\hline ArticleCategory & : & Feature \\
\hline ArticleFirstPage & : & 18 \\
\hline ArticleLastPage & : & 24 \\
\hline ArticleHistory & $:$ & $\begin{array}{ll}\text { RegistrationDate } & : \text { 2007-9-14 } \\
\text { OnlineDate } & : \text { 2007-9-14 }\end{array}$ \\
\hline ArticleCopyright & . & Crown copyright 2007 \\
\hline
\end{tabular}


Karen Dunnell, ${ }^{\text {Aff1 }}$

Fernando Galindo-Rueda, ${ }^{\text {Aff1 }}$

Richard Laux, ${ }^{\text {Aff1 }}$

\section{Provides an overview of the challenges faced by ONS in the ongoing process of social andeconomic integration.}

This article provides an overview of the challenges faced by the Office for National Statistics (ONS) to meet policy and wider evidence needs on the ongoing process of social and economic integration. Globalisation has been singled out by the UK Government as oneof the main challenges and opportunities facing the country. Migration is the main work priority for ONS in this area. Other crucial challenges are posed by new forms of "weightless" trade, increasing specialisation in internationally engaged firms, greater importance of intangibleinvestment, unprecedented financial integration and the wide range of social and economic impacts on the population. This article documents the progress made towards meeting these challenges, and concludes that increased, and more focused, interdepartmental and international co-operation is needed. Italso invites external contributions to the ongoing consultation on the future ONS work programme.

Misc

The Full Text of this article can be found on the National Statistics website (http://www.statistics.gov.uk/elmr/09_07/downloads/ELMR09_07Globalisation.pdf). 